\title{
Lymphocyte-Specific Protein 1
}

National Cancer Institute

\section{Source}

National Cancer Institute. Lymphocyte-Specific Protein 1. NCI Thesaurus. Code C68715.

Lymphocyte-specific protein 1 (339 aa, 37 kDa) is encoded by the human LSP1 gene.

This protein binds actin and may play a role in neutrophil functions including motility, adhesion to fibrinog en matrix proteins, and transendothelial migration. 